the Annual Meeting and issues of representation and governance.

\section{Other Actions}

The Council commended the SPC for its excellent report, approved the budget for FY2001 presented by Treasurer James Stimson (see accompanying Treasurer's Report), approved a series of proposals from the Annual Meeting Committee but asked the committee to reconsider the two-appearance rule, clarified the guidelines concerning eligibility for dissertation awards, and approved the formation of a new Or- ganized Section on Comparative Democratization.

The complete draft minutes of the August 31 Council meeting are printed in the Gazette section of this issue of $P S$.

\section{Council Votes to Expand APSA Journals}

After a spirited debate at its August 31 meeting, the APSA Council unanimously approved the following motion.

The APSA will publish expanded book reviews and more integrative essays no later than

\title{
Lee Sigelman Chosen as Next APSR Editor
}

Lee Sigelman, professor of political science and Columbian Professor, George Washington University, was unanimously approved by the Council to serve as the next editor of the American Political Science Review. Sigelman will begin his three-year term on September 1, 2001.

APSA President Robert Keohane proposed Sigelman, who was the unanimous choice of the editorial search committee composed of Peter Gourevitch, chair, University of California, San Diego; Robert Jervis, Columbia University; Gary King, Harvard University; Arlene Saxonhouse, University of Michigan, Ann Arbor; and Katherine Tate, University of California, Irvine. Commenting on the work of the committee, Keohane said, "In my judgment, it did its work extremely well: thoroughly, fairly, collegially, and expeditiously."

Sigelman is a former editor of American Politics Quarterly and a current deputy editor of Social Science Quarterly. He has served as chair of the political science departments at the University of Kentucky and George Washington University, and is author or coauthor of eight books and over 200 articles in refereed journals, several of which have appeared in the APSR. The fields in which he has published include comparative politics, public opinion/political behavior, bureaucracy and administration, the study of political executives, and methodology.

Sigelman "clearly has the requisite abilities and personal characteristics for an editor of the Review," Keohane wrote in his memo to the Council. "He writes well. . . . communicates effectively with people in other subfields of the discipline, and enjoys reaching out to different constituencies. He . will ensure that manuscripts flow quickly to reviewers and will read them promptly and thoroughly himself."

Keohane said that he wanted to make sure that the person he nominated to be editor "understands the depth and breadth of criticism of the Review in the profession. It is clear to me that he does. . . I think that his combination of energy, openness, and commitment to the highest standards of scholarship will make him a great editor."

Lee Sigelman's memo to the Council briefly explicating his vision and plans for APSR can be found at wuw.apsanet.org/new/ sigelmanplan.cfm.
January 2003 in a form-electronic and/or print, in an existing or new publication-to be decided. An ad hoc Publications Implementation Committee, appointed by the president and approved by the Council will be established to recommend to the Council plans to carry out this resolution. The committee will report to the Council at its next meeting, April 21, 2001, and will have a completed plan in place for Council approval in time for its August 29, 2001 meeting.

This motion arose in the context of the report of the Strategic Planning Committee, "Planning Our Future" (reprinted in this issue of $P S$ ), and a competing proposal of the Publications Committee concerning the creation of a new journal. APSA President Robert Jervis, Columbia University, has named Helen Milner, chair, Columbia University; William J. Ball, The College of New Jersey; Gary King, Harvard University; Jeffrey Legro, University of Virginia; Cheryl Miller, University of Maryland, Baltimore County; Bert Rockman, University of Pittsburgh; and Lee Sigelman, George Washington University, to the ad hoc committee. Members of the Publications Implementation Committee and Council must make several substantive decisions rapidly if they are to formulate a realistic, fundable plan for discussion by the membership in the summer of 2001 and for adjustments and approval by the end of August. Foremost among these is, "Will there be a separate journal?"

If the committee members determine a new journal should be developed, they must then decide what, if anything, it should incorporate. In other words, they must specify how its offerings would differ from or complement those of APSA's existing print journals, $A P S R$ and $P S$, and its online materials on APSAnet. Specifc questions they will have to address include: Would it be wise to strip the highly popular book reviews from the $A P S R$, making these the heart of the new journal? Might doing so risk leaving the discipline's flagship journal with a shrinking audience? And, might the new journal include state-of-thediscipline essays, literature reviews, 
integrative essays linking work in various subfields, and policy studies in addition to book reviews and book review essays? If so, are these featured studies to be peer reviewed? Relatedly, what sort of peer review is possible when articles are commissioned? Finally, in regard to content, the committee must consider whether a single editor can adequately handle the review and publication of several different kinds of articles.

Beyond considerations of content, committee members would have to outline a plan for distributing a new journal to members. Questions begged by this issue include: Is it possible to have an electronic journal of record, possibly accompanied by a briefer print version or by a complete paper version printed only once a year? Will a proposal to distribute this journal electronically meet the same opposition that the SPC's initial electronic plans for the APSR encountered? And, should members be able to select which journals they receive?

Perhaps trumping all other considerations, even though it must necessarily be the last taken, is "How will development of new journal be funded?"

If committee members decide against creating a new journal, they must put forth a plan for fulfilling the resolution to publish expanded book reviews and more integrative essays by retooling APSR, PS, or APSAnet. Regardless of their decision on how best to accomplish the goal, committee members must remain focused on the resolution's call for providing a forum for articles that bridge differences among members of the discipline and demonstrate the coherence of political science.

\section{Principles to Guide Committee Deliberations}

In a memorandum prepared following the Council resolution, Executive Director Catherine Rudder proposed that the following principles and goals be followed in making the decisions necessary to implement the Council's intentions.
- APSA membership should include as many individual benefits as possible without additional charge beyond the membership fee, though it may not be feasible for this principle to be followed in every case. [Articulated by the Administrative Committee, August 29, 2000.]

- Every political scientist should help pay for collective goods provided by APSA and should be charged according to ability to pay. Free riding within the profession should be strongly discouraged and made as difficult as possible. [Articulated by the Administrative Committee, August 29, 2000.]

- Outside the profession, free riding for teaching and scholarship (i.e., noncommercial use by schools, public libraries, and academic libraries in developing countries) should be permitted to the degree such provision does not create free riding among political scientists who should contribute to the collective good and to the extent that we can afford such provision.

- APSA should retain the rights to all our electronic materials and should not grant exclusivity to any single provider.

\section{Goals for the Committee}

- Membership retention and growth with the eventual goal of having the majority of academic political scientists belong to APSA (this goal should keep our fees for membership and related charges in line and should keep a market check on what choices we make)
- Universal distribution of our scolarship to the degree that finances permit

- More breadth in coverage through features that integrate our discipline in our journal offerings

- Maintenance of the high quality of our journals

- More space devoted to book reviews and to research articles

- Ability to speak to a broader public and to bring our research to the attention of serious policymakers

- Journal offerings of substantial use to political scientists as producers and users of scholarship for research and as teachers, both at the graduate and undergraduate levels

- Widespread acceptance of electronic publication within the profession and maximum use of the potentiality of digitalization to further scholarship and its distribution

- Exploration of the creation of a discipline-wide political science consortium linking the electronic versions of political science journals

- Creation of an electronic-only membership

- Ability to offer APSA goods and services, such as PROceedings, APSR online, and PSOnline, in a variety of ways to nonmembers in such a way as to encourage membership among political scientists and to maximize revenues from sales to nonmembers.

Member's comments on any aspect of the Council resolution and its implementation are welcome at apsa@apsanet.org.

\section{Committee Suggestions Welcomed}

APSA welcomes suggestions for individuals interested in serving on APSA standing committees for terms beginning January 1, 2002. Appointments vary from one to three years. A list of committees and their respective areas of responsibility can be found in the March 2000 issue of PS or online at www.apsanet.org/about/ governance/committeemain.cfm. These positions are held on a volunteer basis. Interested members should make their suggestions by mail to President-Elect Robert Putnam, c/o APSA, 1527 New Hampshire Ave., NW, Washington, DC 200361206 or by email to nominations@apsanet.org. 
Council Approves Free One-Year Membership for New Ph.D. Students

The APSA Council approved a new program to offer free one-year memberships for firstor second-year Ph.D. students. The Association and graduate departments would team up to provide the memberships, with the doctoral programs supplying APSA with an accurate list of names and mailing addresses for their first- and second-year Ph.D. students and also splitting the costs of the referred students' memberships.

The Council believes offering students free Association memberships at the start of their doctoral studies will help speed their integration into the profession. Secondary goals are to have faculty in Ph.D.-granting departments encourage their students to join APSA and to enlarge the pool of potential life-long Association members.

Second-year Council member Eileen McDonagh of Northeastern University proposed offering the free memberships at the April meeting of the Council. University of North Carolina professor and APSA Treasurer James Stimson worked with APSA staff over the summer to iron out the details and came forward with McDonagh's proposal in August. The full Council approved the measure with minor amendments.

The Council was also briefed on a proposal to extend free subscriptions to the Personnel Service Newsletter to graduate student members. However, no action was asked for or taken at the August meeting.

Currently, the Association offers several benefits targeted at student members. These include:

- lower membership dues

- dissertation awards

- minority identification and fellowship programs

- regular placement reports

- a web page for graduate students, "The Graduate Student Connection"

(www.apsanet.org/opps/grad)

- graduate student travel grants to the Annual Meeting

- eJobs and the Annual Meeting placement service

- articles of particular interest to graduate students in PS

- programs of particular interest to first-time teachers, like the syllabi project, the Coalition on the Academic Workforce, and the Preparing Future Faculty program

- two special receptions at the Annual Meeting

- a soon-to-be-published guide to finding nonfaculty jobs.

\section{Conference for Political Science Department Chairs}

Panelists and department chairs from over 30 graduate and undergraduate departments participated in an intriguing discussion of departmental responsibility for professional training and career success at the 2000 Conference for Political Science Department Chairs. The co- chairs of the conference were Charles Johnson, chair of the Committee on Education and Professional Development and of the political science department at Texas A\&M University, and Ron Peters, chair of the Departmental Services Committee and of the political sci- ence department at University of Oklahoma. Panelists included David Breaux, Mississippi State University; Anne Costain, University of Colorado, Boulder; William E. Hudson, Providence College; and Barry Rundquist, University of Illinois, Chicago. The conference was on Wednesday's Professional Day held during the APSA Annual Meeting.

The primary catalyst of the discussion was the report from the Committee on Education and Professional Development on how the profession can address the preparation and placement of political science Ph.D.s and support the professional development of newly appointed faculty. Department chairs and faculty are invited to review "Department Responsibilities for Doctoral Programs and Employment in the Discipline: A Report of the APSA Committee on Education and Professional Development"online (www.apsanet.org/about/chairs/ responsibilities.cfm) and send comments and suggestions to dsp@apsanet.org.

The objective of the report is to strategically facilitate departmental initiatives and activities on behalf of doctoral professional education and continuing professional development of new faculty as well as to help prospective Ph.D. students make informed decisions when choosing a doctoral program and to assist new faculty in learning about prospective employers. The committee's principal suggestions for accomplishing these objectives were to create (1) a voluntary "roster" of Ph.D. departments and the efforts they report making to train doctoral graduates for their scholarly and faculty responsibilities, and (2) a voluntary "register" of departments indicating which provide support for the career development of their junior faculty and what kind of support is offered.

Information collected for the roster and registry could be used to develop guidelines for the types of resources departments should make available to students and faculty.

The participating department chairs favored the objectives of the proposed programs, but recommended modifications in the design and implementation. The Committee is revising the report in response to the suggestions. 